\title{
Characterization of atmospheric aerosols for a long range transport of biomass burning particles from Canadian forest fires over the southern Iberian Peninsula in July 2013
}

\section{Caracterización del aerosol atmosférico en un evento de transporte a gran distancia de partículas de combustión de biomasa procedente de incendios de Canadá en julio de 2013 sobre el sur de la Península Ibérica}

\author{
P. Ortiz-Amezcua(1,2), J. L. Guerrero-Rascado(1,2,*), M. J. Granados-Muñoz ${ }^{(1,2)}$, \\ J. A. Bravo-Aranda ${ }^{(1,2)}$, L. Alados-Arboledas ${ }^{(1,2)}$ \\ 1. Andalusian Institute for Earth System Research (IISTA-CEAMA), University of Granada, Autonomous \\ Government of Andalusia, Av. del Mediterráneo s/n, 18006, Granada, Spain \\ 2. Department of Applied Physics, University of Granada, Fuentenueva s/n, 18071, Granada, Spain, \\ ${ }^{(*)}$ Email: rascado@ugr.es $\quad$ S: miembro de SEDOPTICA / SEDOPTICA member \\ Received / Recibido: 13/12/2013. Revised / Revisado: 26/02/2014. Accepted / Aceptado: 27/02/2014. \\ DOI: http://dx.doi.org/10.7149/OPA.47.1.43
}

\begin{abstract}
:
This work presents the characterization of aerosols during a special episode of long-range transported biomass burning particles from Canadian forest fires. This event was detected at the EARLINET Granada station $\left(37.16^{\circ} \mathrm{N}, 3.61^{\circ} \mathrm{W}, 680 \mathrm{~m}\right.$ asl) from $11^{\text {th }}$ to $17^{\text {th }}$ July 2013 , and also over other EARLINET stations. Different techniques, covering active/passive and ground based/satellite ones, have been used. In particular, the study has involved processing of both Raman and elastic lidar signals and sun-photometer AERONET data. Furthermore, modeling tools as HYSPLIT, NAAPS and BSC-DREAM8b have been used to understand the synoptic behavior of the aerosol plumes. The results highlight the presence of a multilayered structure showing large backscatter-related Angstrom Exponent (around 2) and very low particle linear depolarization (less than 0.04) at layers around 5-6 km (asl) which means considerably small and spherical particles. During the strongest period, on $14^{\text {th }}$ July, aerosol backscatter values up to $2.9 \times 10^{-6}(\mathrm{~m} \mathrm{sr})^{-1}$ at $532 \mathrm{~nm}$ were detected in this layer.
\end{abstract}

Key words: AERONET, Canadian Biomass Burning Particles, EARLINET, Lidar, Long-Range Transport, Sun-Photometer.

\section{RESUMEN:}

Este trabajo presenta la caracterización, durante un evento especial de transporte a gran distancia, de partículas de combustión de biomasa, procedentes de incendios forestales en Canadá. El evento se detectó entre el 11 y el 17 de julio de 2013 en la estación de EARLINET en Granada $\left(37.16^{\circ} \mathrm{N}, 3.61^{\circ}\right.$ W, $680 \mathrm{snm}$ ), así como en otras estaciones de EARLINET. Para su caracterización se han usado diferentes técnicas, incluyendo activas/pasivas y terrestres/por satélite. En particular, el estudio implicó el procesado de señales lidar tanto elásticas como Raman, y datos de fotómetro solar de la red AERONET. Además se han usado modelos como HYSPLIT, NAAPS y BSC-DREAM8b para investigar el comportamiento de las plumas de aerosol a escala sinóptica. Los resultados destacan la presencia de una estructura con múltiples capas que muestran un exponente de Angstrom de coeficiente de retrodispersión alto (aproximadamente 2) y una despolarización lineal de partículas muy baja (menos de 0.04) en las capas a 5-6 km (snm) de altura, lo que indica que son partículas considerablemente pequeñas y esféricas. Durante el período más intenso, el 14 de julio, se detectaron valores del coeficiente de retrodispersión de hasta $2.9 \times 10^{-6}\left(\mathrm{~m} \mathrm{sr}^{-1}\right.$ para $532 \mathrm{~nm}$.

Palabras clave: AERONET, EARLINET, Fotómetro Solar, Lidar, Partículas de Combustión de Biomasa Canadienses, Transporte a Larga Distancia. 


\section{REFERENCES AND LINKS / REFERENCIAS Y ENLACES}

[1]. J. L. Guerrero-Rascado, F. J. Olmo, F. Molero, F. Navas-Guzmán, M. J. Costa, A. M. Silva, M. Pujadas, M. Sicard, L. Alados-Arboledas, "Aerosol direct radiative effects of a transatlantic biomass burning plume over Granada, Spain”, IV Reunión Española de Ciencia y Tecnología del Aerosol -RECTA, C7-1-C7-6 (2010).

[2]. J. L. Guerrero-Rascado, F. J. Olmo, F. Molero, F. Navas-Guzmán, M. J. Costa, A. M. Silva, M. Pujadas, M. Sicard, L. Alados-Arboledas, "Characterization of atmospheric aerosols for a long-range transport of biomass-burning from North America over the Iberian Peninsula", Proceedings 25th International Laser Radar Conference, pp. 580-583 (2011).

[3]. L. Alados-Arboledas, D. Müller, J. L. Guerrero-Rascado, F. Navas-Guzmán, D. Pérez-Ramírez, and F. J. Olmo, "Optical and microphysical properties of fresh biomass burning aerosol retrieved by Raman lidar, and star- and sun-photometry", Geophys. Res. Lett. 38, L01807 (2011). DOI

[4]. J. Bösenberg, A. Ansmann, J. M. Baldasano, D. Balis, C. Böckmann, B. Calpini, A. Chaikovsky, P. Flamant, A. Hagrard, V. Mitev, A. Papayannis, J. Pelon, D. Resendes, J. Schneider, N. Spinelli, T. Trickl, G. Vaughan, G. Visconti, M. Wiegner, "EARLINET: a European aerosol research lidar network, laser remote sensing of the atmosphere", pp. 155-158 of selected papers of the 20 ${ }^{\text {th }}$ International Laser Radar Conference, A. Dabas, C. Loth and J. Pelon, Edts., Ecole Polytechnique, Palaiseau, France (2001).

[5]. M. Sicard, A. Comerón, F. Molero, J. L. Guerrero-Rascado, R. Pedrós, F. Javier Expósito, C. CórdobaJabonero, F. Rocadenbosch, M. Pujadas, L. Alados-Arboledas, J. A. Martínez-Lozano, J. P. Díaz, M. Gil, "Aerosol lidar intercomparison in the framework of SPALINET - The SPAnish Lidar NETwork: mothodology and results", IEEE Trans. Geosci. Remote Sens. 47, 3547-3559 (2009). DOI

[6]. B. N. Holben, T. F. Eck, I. Slutscker, D. Tanre, J. P. Buis, A. Setzer, E. Vermote, J. A. Reagan, Y. J. Kaufman, T. Nakajima, F. Lavenu, I. Jankowiak, A. Smirnov, "AERONET - A federated instrument network and data archive for aerosol characterization”, Remote Sens. Environ. 66, 1-16 (1998). DOI

[7]. http://cetemps.aquila.infn.it/mwrnet/

[8]. F. Navas-Guzmán, J.L. Guerrero-Rascado, L. Alados-Arboledas, "Retrieval of the lidar overlap function using Raman signals", Opt. Pura Apl. 44, 71-75 (2011).

[9]. J. L. Guerrero-Rascado, M. João Costa, D. Bortoli, A. M. Silva, H. Lyamani, L. Alados-Arboledas, "Infrared lidar overlap function: an experimental determination", Opt. Express 18, 20350-20359 (2010). DOI

[10]. J. D. Klett, "Stable analytic inversion solution for processing lidar returns", Appl. Opt. 20, 211-220 (1981). DOI

[11]. J. D. Klett, "Lidar inversion with variable backscatter/extinction ratios", Appl. Opt. 24, 1638-1643 (1985).

[12]. F. G. Fernald, B. M. Herman, J. A. Reagan, "Determination of aerosol height distribution by lidar", J. Appl. Meteorol. 11, 482-489 (1972). DOI

[13]. F. G. Fernald, "Analysis of atmospheric lidar observations: some comments", Appl. Opt. 23, 652-653 (1984). DOI

[14]. A. Ansmann, U. Wandinger, M. Riebesell, C. Weitkamp, W. Michaelis, "Independent measurement of extinction and backscatter profiles in cirrus clouds by using a combined Raman elastic-backscatter lidar", Appl. Opt. 31, 7113-7131 (1992). DOI

[15]. J. A. Bravo-Aranda, F. Navas-Guzmán, J. L. Guerrero-Rascado, D. Pérez-Ramírez, M. J. GranadosMuñoz, L. Alados-Arboledas, "Analysis of lidar depolarization calibration procedure and application to the atmospheric aerosol characterization", Int. J. Rem. Sens. 34, 3543-3560 (2013). DOI

[16]. R. R. Draxler, G. D. Rolph, HYSTPLIT (HYbrid Single-Particle Lagrangian Integrated Trajectory) Model, access via NOAA ARL READY Website (http://www.arl.noaa.gov/ready/hysplit4.html), NOAA Air Resources Lab., Silver Spring, MD (2003).

[17].http://www.nrlmry.navy.mil/aerosol.html/

[18]. S. Basart, C. Pérez, S. Nickovic, E. Cuevas, J. M. Baldasano, “Development and evaluation of the BSCDREAM8b dust regional model over Northern Africa, the Mediterranean and the Middle East", Tellus B 64, 1-23 (2012). DOI 


\section{[19].http://firefly.geg.umd.edu/firemap/}

[20]. N. T. O'Neill, O. Dubovik, T. F. Eck, "Modified Anstrom exponent for the characterization of submicrometer aerosols", Appl. Opt. 40, 2368-2375 (2001). DOI

[21]. N. T. O'Neill, T. F. Eck, A. Holben, S. Thulasiraman, "Spectral discrimination of coarse and fine mode optical depth", J. Geophys. Res. 108, 4559 (2003). DOI

[22]. M. J. Granados-Muñoz, J. L. Guerrero-Rascado, J. A. Bravo-Aranda, F. Navas-Guzmán, A. Valenzuela, H. Lyamani, A. Chaikovsky, U. Wandiger, A. Ansmann, O. Dubovik, J. O. Grudo, L. Alados-Arboledas, "Retrieving aerosol microphysical properties by LIdar-Radiometer Inversion Code (LIRIC) for different aerosol types", J. Geophys. Res. in press.

\section{Introduction}

In recent years, the important role of atmospheric aerosols on climate has been studied in several works that focus both on direct and indirect effects. Particularly, it have been demonstrated that biomass burning particles produce a considerable impact on local radiative properties of the atmosphere [1], both by absorbing and scattering shortwave radiation. For this reason, all studies made in order to typify and characterize such aerosols are relevant for a better understanding of the complex system of atmospheric radiative transfer and the Earth's radiation budget. Likewise, comparable studies have been made for the same aerosol type (biomass burning particles) and both for medium- and long-range transport [2, 3]. Studying the same kind of particles at a different transport time is crucial to figure out the ageing processes involved.

This work presents a general optical characterization of a strong plume of long-range transported biomass burning particles from Canadian forest fires, registered over Southern Iberian Peninsula in July 2013. The aim is to identify the layers in terms of aerosol backscatter coefficient vertical profiles, and then characterize the changes in variables like Angstrom Exponent and particle linear depolarization ratio, compared to days after and before the arrival of the plume.

\section{Experimental site, instrumentation and methodology}

The instrumentation used to acquire the data used in this study is located at the Andalusian Institute for Earth System Research (IISTACEAMA) in Granada $\left(37.16^{\circ} \mathrm{N}, 3.61^{\circ} \mathrm{W}, 680 \mathrm{~m}\right.$ above sea level). This city is located in Southern
Spain. The station is included in several research networks like EARLINET (European Aerosol Research Lidar Network) [4], SPALINET (Spanish and Portuguese Lidar Network) [5], AERONET (Aerosol Robotic Network) [6] and MWRNET [7].

The vertical profiles used in this work were acquired using a multiwavelength Raman lidar system (LR331D400), configured in a monostatic biaxial alignment pointing vertically to the zenith. The light source is a pulsed Nd:YAG laser with fundamental wavelength at $1064 \mathrm{~nm}$, and additional emissions at 532 and $355 \mathrm{~nm}$, which are obtained by using second and third harmonic generators. The radiation is collected by a $40 \mathrm{~cm}$-diameter receiving Cassegranian telescope, and then the radiation is split into seven channels allowing the detection of elastic signals at 1064, 355 and $532 \mathrm{~nm}$ (in parallel and perpendicular polarizations) and three Raman channels at 387 and $607 \mathrm{~nm}$ (nitrogen Ramanshifted signal from 355 and $532 \mathrm{~nm}$, respectively) and $408 \mathrm{~nm}$ (water vapour Ramanshifted signal from $355 \mathrm{~nm}$ ). The spatial resolution is $7.5 \mathrm{~m}$ and the temporal resolution is $1 \mathrm{~min}$. This instrument has an overlap limitation due to its intrinsic setup, but it will not be taken into account in this work, since our study focuses in heights above $1.7 \mathrm{~km}$ asl [8,9]. The vertical profiles from the lidar signal were retrieved using the Klett-Fernald algorithm [10-13] for daytime signal and Raman algorithm [14] for night time signals.

The atmospheric column over Granada was analyzed in terms of certain aerosol optical properties: aerosol backscatter coefficient $(\beta)$, particle linear depolarization ratio $\left(\delta_{P}\right)$ and backscatter-related Angstrom Exponent ( $\beta$-AE), defined as follows: 


$$
\begin{gathered}
\delta_{P}=\frac{R \delta\left(\delta_{m}+1\right)-\delta_{m}(\delta+1)}{R\left(\delta_{m}+1\right)-(\delta+1)}, \\
A E=-\frac{\ln \left[\frac{\beta\left(\lambda_{1}\right)}{\beta\left(\lambda_{2}\right)}\right]}{\ln \left[\frac{\lambda_{1}}{\lambda_{2}}\right]},
\end{gathered}
$$

In $\delta_{P}$ equation, $R$ is the backscattering ratio defined as the ratio of total (particle plus molecule) to molecular backscatter coefficients, $\delta$ is the volume linear depolarization ratio calibrated following [15] and $\delta_{m}$ is the molecular linear depolarization ratio. The $\delta_{P}$ values provide information on the predominance of spherical versus non-spherical particles. The $\beta$ related $\mathrm{AE}$ describes the spectral dependence of aerosol backscatter coefficient. It is believed to be dominated by particle size and shape.

In our analyses some data retrieved from the CIMEL CE-138 sun-photometer are also used. This instrument measures solar transmissions, aureole and sky radiances through a large range of scattering angles. The automatic tracking Sun and sky scanning radiometers made direct Sun measurements with a $1,2^{\circ}$ full field of view every $15 \mathrm{~min}$ at 340, 380, 440, 500, 675, 870, 940 and $1020 \mathrm{~nm}$ (nominal wavelengths). These solar extinction measurements are then used to compute aerosol optical depth at each wavelength except for the $940 \mathrm{~nm}$ channel, which is used to retrieve total column water vapour. A more complete description can be found in [6].

In order to know about the synoptic movement of the aerosol plumes before arriving to our station, some modelling tools were employed. With HYSPLIT (Hybrid Single-Particle Lagrangian Integrated Trajectory) [16] one can calculate back-trajectories and dispersion, particle concentration and deposition processes using a Lagrangian model and meteorological data from GDAS database. NAAPS (Navy Aerosol Analysis and Prediction System) model of Marine Meteorology Division, Naval Research Laboratory (NRL) [17] provides predictions of aerosol optical depth and surface particle density of sulphate, mineral dust and smoke. Finally, BSC-DREAM8b (Dust Regional Atmospheric Model) [18] gives maps showing the dust load -dust mass per unit section of atmospheric column- and thus allows us to identify desert emitting sources.

\section{Results and discussion}

In the period from $11^{\text {th }}$ to $17^{\text {th }}$ July 2013 , a strong aerosol load in the free troposphere -in terms of aerosol backscatter and extinction coefficientswas detected over our station. Back-trajectories at altitudes of 1000, 2000, 3000, 4000, 5000 and $6000 \mathrm{~m}$ asl were analysed with HYSPLIT model (v4.9) for every day in this period. Figure (1) shows these back-trajectories for the day which best describes the episode, the 14th July (trajectories starting 10 days before). It is seen that the air masses of interest came from the North of Canada, where several wildfires had started the week before and were still burning, as detected by MODIS sensor [19]. The same conclusion can be inferred from the backtrajectories for day $15^{\text {th }}$ July. In contrast, $11^{\text {th }}$ and $12^{\text {th }}$ July trajectories (both calculated starting a week before) show wind coming mainly from Sahara desert and from the North of Spain. Backtrajectories corresponding to the rest of the days in the period (also starting a week before each day) reflect a mix of air masses from Sahara desert and from central Europe.

NAAPS model for the days mentioned has also been analysed (not shown here). This model

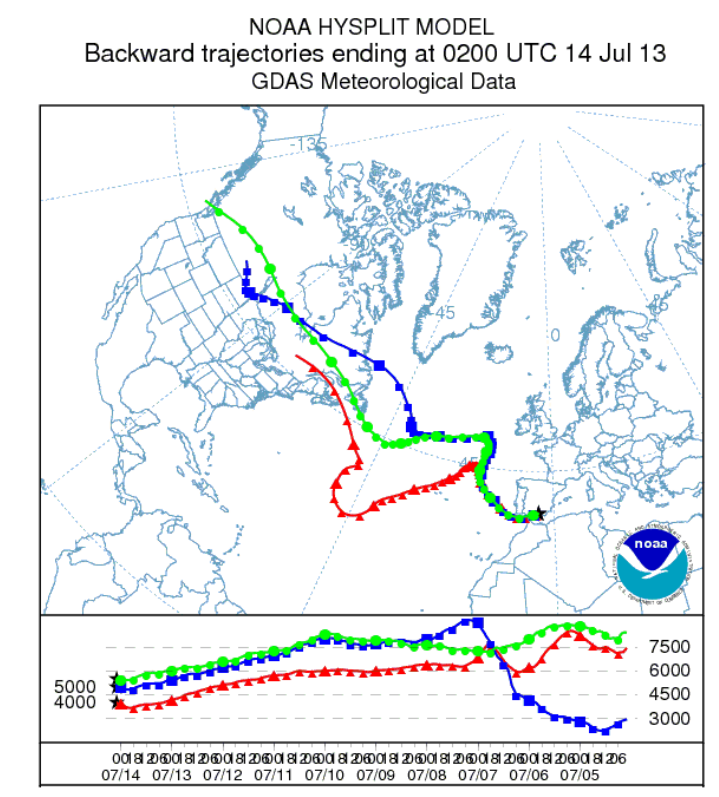

Fig. 1. 10-day back-trajectories of the air masses at altitudes of 4000,5000 and $5500 \mathrm{~m}$ asl on $14^{\text {th }}$ July. 
does not predict any significant surface concentrations of dust, smoke or sulphate. Predictions about dust concentrations, made with BSC-DREAM8b simulation model, show that only on $11^{\text {th }}$ July a dust load, up to $0.25 \mathrm{~g} / \mathrm{m}^{2}$ was forecasted. Looking at these three models, we can understand the synoptic behaviour of the aerosol plumes: according to that, it can be inferred that it is potentially expected a small mineral dust load on $11^{\text {th }}$ July originated in Africa, long-range transported biomass burning particles advected from Canadian forest fires to Granada on days $14^{\text {th }}$ and $15^{\text {th }}$ July, and some anthropogenic aerosol coming from Europe, maybe mixed with remaining smoke on $16^{\text {th }}$ and $17^{\text {th }}$ July. In Fig. (2), the evolution of the lidar range corrected signal (raw lidar signal multiplied by square distance) at $532 \mathrm{~nm}$ is displayed, with altitude above sea level in the vertical axis and time UTC in the horizontal axis. They allow seeing the main aerosol layers at a glance, thus the day of the strongest load, $14^{\text {th }}$ July, can be easily identified. They highlight the presence of a multilayered structure with aerosol particles at high altitudes (around 5-6 $\mathrm{km})$.

Lidar calculations were performed, and the results combined with the models discussed above reveal that on days $14^{\text {th }}$ and $15^{\text {th }}$ July an important plume of biomass burning aerosol passed the free troposphere over Granada. Figure (3b) shows how in $4 \mathrm{~km}$ layers, the aerosol backscatter coefficient undergoes a sharp increase (from $5 \times 10^{-7} \mathrm{~m}^{-1} \mathrm{sr}^{-1}$ to $2 \times 10^{-6}$ $\mathrm{m}^{-1} \mathrm{sr}^{-1}$ at $532 \mathrm{~nm}$ ) compared to the dust layers on $11^{\text {th }}$ July, as seen in Fig. 3(a). This increase occurs parallel to a decrease in the particle
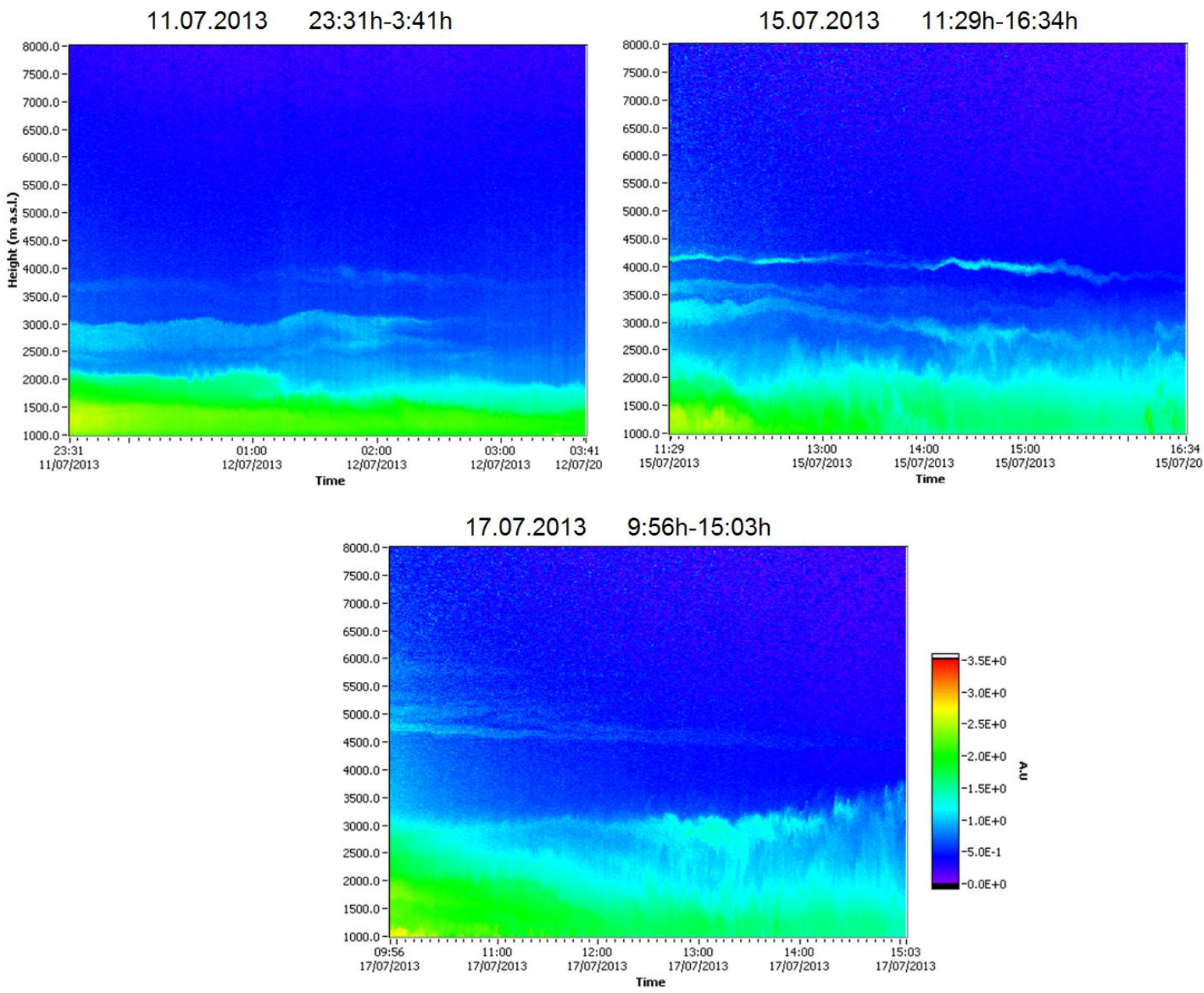

Fig. 2. Time series of lidar range corrected signal at $532 \mathrm{~nm}$ (arbitrary units). 

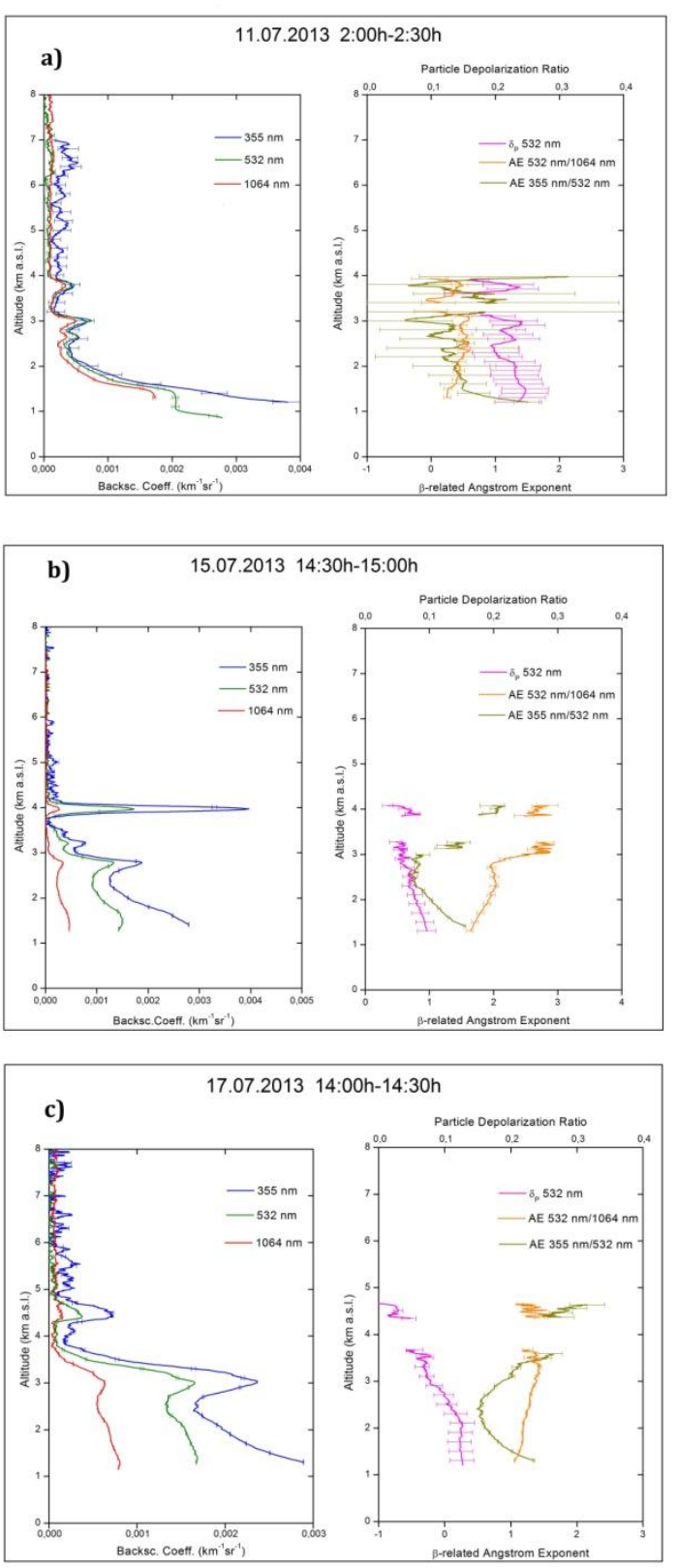

Fig. 3. Vertical profiles retrieved for: (a) $11^{\text {th }}$ July; (b) $15^{\text {th }}$ July; (c) $17^{\text {th }}$ July. Left: backscatter coefficient calculated at 355, 532 and $1064 \mathrm{~nm}$. Right: $\delta_{P}$ and $\beta$-related Angstrom Exponents for the ranges $532-1064 \mathrm{~nm}$ and $355-532 \mathrm{~nm}$.

linear depolarization ratio (which reaches values less than 0.05) and an increase in the backscatter-related Angstrom Exponent (from 0.3 to 2), what means that these biomass burning particles transported along the Atlantic ocean are much smaller and spherical than dust ones $[20,21]$. Coherent results are also obtained from sun-photometer: Fig. 4, representing sunphotometric data, shows that on $14^{\text {th }}$ July, fine mode particles are the main responsible of the

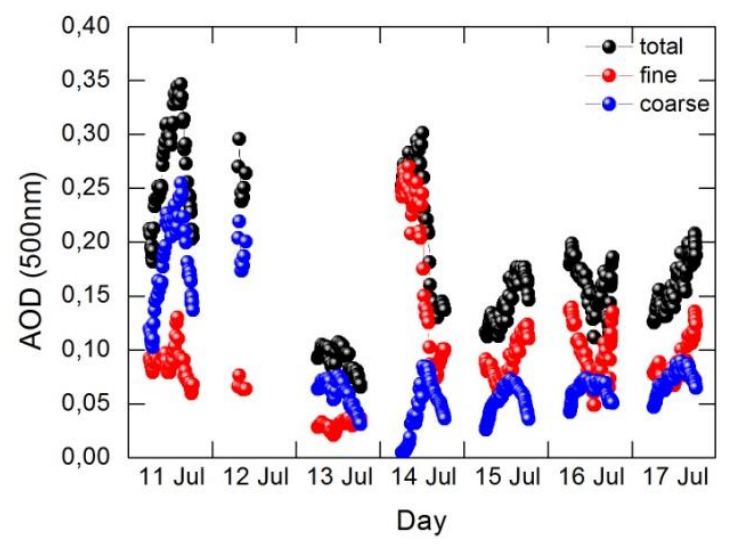

Fig. 4. Aerosol Optical Depth at $500 \mathrm{~nm}$ for the period studied, retrieved from sun-photometer data.

total aerosol optical depth at $500 \mathrm{~nm}$ (around $83 \%$ of the total AOD). Finally, looking at Fig. 3 (c), it can be guessed a certain mixture of layers with high $\beta$-AE and low $\delta_{P}$, and others with the opposite features.

\section{Conclusions}

The location of Granada station is such that different types of aerosol are usually registered: dust particles coming from Sahara desert, anthropogenic aerosol from Europe or biomass burning particles. This study presents a preliminary characterization of particles arriving from Canadian wildfires, after a severalday transatlantic transport with the subsequent aging process. Despite having travelled for more than a week, these particles can produce a strong increase in aerosol backscatter and extinction coefficients in the free troposphere (above $5000 \mathrm{~m}$ asl), as the Raman lidar measurements revealed.

During the studied period, aerosol backscatter coefficient values up to $2.9 \times 10^{-6}$ $(\mathrm{m} \cdot \mathrm{sr})^{-1}$ at $532 \mathrm{~nm}$ were detected in the layers corresponding to biomass burning aerosol. After having investigated the air masses origin, the vertical aerosol optical profiles were analyzed in order to establish an aerosol typing. The analysis of vertical profiles of particle linear depolarization ratio (showing values less than 0.04) and backscatter-related Angstrom Exponent (with values more than 2) reflects that such particles are significantly small and 
spherical. High-quality vertical profiles were obtained for this special episode, what makes motivating to follow with the study in order to obtain accurate optical properties of the layer, such as layer-mean lidar ratio and layer-mean Angstrom Exponent, and microphysical properties derived by LIRIC [22].

\section{Acknowledgements}

This work was supported by the Spanish Ministry of Science and Technology through projects CGL2008-01330-E/CLI (Spanish and Portuguese Lidar Network), CGL2010-18782 and CSD2007-00067; by Andalusian Regional Government through projects P10-RNM-6299 and P08-RNM-3568; and by EU through ACTRIS project (EU INFRA-2010-1.1.16-262254). The authors thankfully acknowledge the computer resources, technical expertise and assistance provided by Barcelona Supercomputing Center for the BSC-DREAM8b model dust data. The authors express gratitude to the NOAA Air Resources Laboratory (ARL) for the HYSPLIT transport and dispersion model. We thank those at NRL-Monterey that have helped in the development of the NAAPS model and to the MODIS team for the use of FIRMS data. 